\title{
Activity of cathepsins during beef aging related to mutations in the myostatin gene
}

\author{
Beatriz Caballero, ${ }^{1 \dagger}$ Verónica Sierra, ${ }^{1 \dagger}$ Mamen Oliván, ${ }^{2}$ Ignacio Vega-Naredo, ${ }^{1}$ \\ Cristina Tomás-Zapico, ${ }^{1}$ Óscar Alvarez-García, ${ }^{1}$ Delio Tolivia, ${ }^{1}$ Rüdiger Hardeland, ${ }^{3}$ \\ María Josefa Rodríguez-Colunga ${ }^{1}$ and Ana Coto-Montes ${ }^{1 *}$ \\ ${ }^{1}$ Departamento de Morfología y Biología Celular, Universidad de Oviedo, E-33006 Oviedo, Asturias, Spain \\ ${ }^{2}$ SERIDA (Servicio Regional de Investigación y Desarrollo Agroalimentario), Apartado 13, E-33300 Villaviciosa, Asturias, Spain \\ ${ }^{3}$ Institut für Zoologie, Anthropologie und Entwicklungsbiologie der Universität, D-37073 Göttingen, Germany
}

\begin{abstract}
Double-muscled syndrome in cattle improves meat tenderness. However, the nature of the proteolytic processes associated with this phenomenon remains unknown. The aim of this study was to monitor changes in the activity of cathepsins $(B, B+L, D$ and $H)$ during meat aging and their gradual release from lysosomes to the cytosol in the longissimus muscle of yearling bulls of two breeds from northern Spain (Asturiana de los Valles and Asturiana de la Montaña) showing three genotypes for muscular hypertrophy $(m h / m h, m h /+$ and $+/+)$. The data showed that the pattern of cathepsin activity during meat aging paralleled variations in tenderness in the different genotypes studied. Maximal cathepsin $D$ activity and minimal cathepsin $H$ activity were recorded during meat aging times ranging from 3 to 21 days. The activities of cathepsins $B$ and $B+L$ were lower than that of cathepsin $D$ at the established time points $(3,7,14$ and 21 days post-slaughter). The role of these enzymes in the activation of cathepsin $D$ is discussed. All cathepsins showed similar action patterns, with high levels early on in the aging process and lower levels at later times. This pattern depended on the genotype and was significantly faster $(P \leq 0.05)$ in meat from $\mathrm{mh} / \mathrm{mh}$ animals, intermediate in meat from $\mathrm{mh} /+$ animals and slower in meat from normal $(+I+)$ animals of both breeds.
\end{abstract}

(c) 2006 Society of Chemical Industry

Keywords: cathepsins; aging; beef; Asturiana de los Valles; Asturiana de la Montaña; proteolysis

\section{INTRODUCTION}

Meat aging is one of the most important processes for obtaining the most satisfactory degree of meat tenderness, which is decisive for consumer selection and acceptability.

The process of meat aging is largely a consequence of enzymatic degradation of key myofibrillar and cytoskeletal proteins that, under in vivo conditions, maintain the structural integrity of myofibrils. ${ }^{1}$ Thus their destruction causes disintegration of the $\mathrm{Z}$ disc, ${ }^{2}$ loss of transversal alignment of sarcomeres and longitudinal splitting of myofibrils; ${ }^{3}$ as a consequence, the muscle weakens and the meat becomes tender.

This post mortem process is produced by endogenous proteolytic enzymes in muscle tissue. Two main proteolytic endogenous systems have been characterised as being responsible for myofibrillar changes during meat aging: calpains/calpastatins and cathepsins/cystatins. The calcium-dependent calpain system has been described as the main factor responsible for increasing tenderness in the early $(0-24 \mathrm{~h})$ post mortem period, ${ }^{4-6}$ because at this stage the $\mathrm{pH}$ (neutral) and temperature (high) of the muscle are favourable for its activity. Nevertheless, lysosomal cathepsins may be involved in later tenderisation processes when $\mathrm{pH}$ conditions are favourable for acidic enzymes. ${ }^{6}$ Sentandreu et $a .^{7}$ suggested that meat tenderisation may result from the synergistic, but not necessarily simultaneous, action of both calpains and cathepsins.

It has been found that this post mortem proteolytic process varies among species ${ }^{8}$ and among different muscle types. ${ }^{9,10}$ Because of this, the rate and extent of post mortem proteolysis of key myofibrillar proteins are a major source of variation in beef tenderness ${ }^{11}$ and could be responsible for differences in tenderisation rate observed among different beef breeds or genotypes. ${ }^{12,13}$

Double-muscled syndrome, characterised by exceptional muscle development, ${ }^{14}$ has been described in several European cattle breeds such as Belgian Blue, Piamontese and Charolais, as well as in one of the main cattle breeds in northern Spain, Asturiana de los Valles. The double-muscled condition is characterised by an increase in muscle mass of about $20 \%$ due to skeletal muscle hyperplasia (an increase in the number of muscle fibres). This has attracted the

* Correspondence to: Ana Coto-Montes, Departamento de Morfología y Biología Celular, Facultad de Medicina, C/Julián Clavería, s/n, E-33006 Oviedo, Spain E-mail: acoto@uniovi.es

${ }^{\dagger}$ Authors contributed equally to this paper

Contract/grant sponsor: INIA (Instituto Nacional de Investigación y Tecnología Agraria y Alimentaria); contract/grant number: SC00-14; CAL03-074-C2 (Received 18 March 2005; revised version received 21 December 2005; accepted 15 June 2006)

Published online 17 November 2006; DOI: 10.1002/jsfa.2683 
attention of beef producers because of an improved carcass performance and better price. Also, meat from double-muscled animals is more tender ${ }^{15}$ and has a low intramuscular fat content ${ }^{16}$ compared with meat from animals with a normal muscle configuration.

Double muscling in cattle is the result of an inactivating mutation in the myostatin gene, ${ }^{17}$ which is a negative regulator of muscle mass. ${ }^{18}$ In the bovine breed examined here, an $11 \mathrm{bp}$ deletion in the coding sequence for myostatin causes excessive muscular growth. ${ }^{17}$ From the point of view of muscular hypertrophy $(m h)$, animals can be homozygous $(m h / m h)$, heterozygous $(m h /+)$ or normal $(+/+)$, displaying a wide range of muscular development between the two extremes.

The aim of this study was to establish the courses of activity of cathepsins $(\mathrm{B}, \mathrm{B}+\mathrm{L}, \mathrm{D}$ and $\mathrm{H})$ under natural post mortem conditions in the longissimus muscle of yearling bulls of two breeds from northern Spain, Asturiana de los Valles and Asturiana de la Montaña. These bulls showed the three possibles genotypes for muscular hypertrophy $(m h / m h, m h /+$ and $+/+)$. Experiments on cathepsin activities were performed on two types of extract (lysosomal and cytosolic) in order to monitor the gradual release of these proteolytic enzymes from lysosomes to the cytosol and thus obtain information on the differential contribution of both compartments to the tenderisation process.

\section{MATERIALS AND METHODS}

\section{Animals and sampling procedure}

Twenty yearling bulls of two local breeds from northern Spain, Asturiana de los Valles (AV) and Asturiana de la Montaña (AM), were studied. Animals of the AV breed were homozygous $(\mathrm{mh} / \mathrm{mh})$, heterozygous $(m h /+)$ or normal $(+/+)$ for muscular hypertrophy. All animals of the AM breed were normal $(+/+)$ for muscular hypertrophy owing to the lack of this genetic modification in this rustic breed. Five animals $(n=5)$ showing each genotype were used.

Animals were slaughtered between 14 and 18 months of age at approximately $500 \mathrm{~kg}$ live weight. Calves were managed with their mothers from birth (winter) to weaning (October). After weaning, the male calves were fed a concentrate $\left(840 \mathrm{~g} \mathrm{~kg}^{-1}\right.$ barley meal, $100 \mathrm{~g} \mathrm{~kg}^{-1}$ soya meal, $30 \mathrm{~g} \mathrm{~kg}^{-1} \mathrm{fat}, 30 \mathrm{~g} \mathrm{~kg}^{-1}$ minerals, vitamins and oligoelements) and barley straw ad libitum for about 5 months before slaughter.

Slaughtering was performed in a commercial abattoir according to a routine procedure. Animal carcasses were transferred to a cold room at $4{ }^{\circ} \mathrm{C}$ within $1 \mathrm{~h}$ of slaughter.

At $24 \mathrm{~h}$ post-slaughter the left half of the carcass was quartered by cutting between the fifth and sixth thoracic vertebrae with a circular saw, as done for commercial purposes. Immediately, the $\mathrm{pH}\left(\mathrm{pH}_{24}\right)$ of the longissimus dorsi (LD) muscle of the fifth rib was determined using a penetration electrode. The LD muscle was then sliced, vacuum packed and transported to the laboratory. From each animal, four $80 \mathrm{~g}$ samples were obtained for the enzyme assays and were left to age at $4{ }^{\circ} \mathrm{C}$ for $3,7,14$ and 21 days, while three larger samples $(3 \mathrm{~cm}$ thick steaks of around $250 \mathrm{~g}$ ) were obtained for texture analysis and aged for 7,14 and 21 days. As an exception, samples of the homozygous $(\mathrm{mh} / \mathrm{mh}) \mathrm{AV}$ genotype were aged for 3, 7 and 14 days for both the enzyme and texture analyses, since previous research has indicated that meat tenderisation is faster in double-muscled yearling bulls than any other biological type. ${ }^{12,19}$

After aging, the tissue samples for the enzyme assays were frozen in liquid nitrogen and stored at $-70^{\circ} \mathrm{C}$, while those for the texture tests were stored at $-20^{\circ} \mathrm{C}$.

\section{Enzyme assays}

\section{Isolation of lysosomes}

After thawing, lysosomal and cytosolic extracts were prepared according to the method of Béchet et al. ${ }^{20}$ with minor modifications. ${ }^{21}$ Enzyme activities were examined independently. Samples $(5 \mathrm{~g}$ of muscle tissue) were homogenised in $45 \mathrm{~mL}$ of homogenisation buffer $\left(10 \mathrm{mmol} \mathrm{L}^{-1}\right.$ potassium phosphate, $\mathrm{pH}$ 7.4, containing $1 \mathrm{mmol} \mathrm{L}^{-1}$ ethylene diamine tetraacetic acid (EDTA), $50 \mathrm{mmol} \mathrm{L}^{-1}$ sodium chloride and $250 \mathrm{mmol} \mathrm{L}^{-1}$ sucrose) using a Polytron PT 3000 homogeniser (Kinematica AG, Lucerne, Switzerland) for $60 \mathrm{~s}$ at maximum speed. The homogenate was centrifuged at $1000 \times g$ for $10 \mathrm{~min}$ at $2^{\circ} \mathrm{C}$ and the supernatant was subsequently centrifuged at $2500 \times g$ for $15 \mathrm{~min}$.

The pellet containing the myofibrillar fraction was discarded and the supernatant containing most of the intracytoplasmic organelles was centrifuged at $20000 \times g$ for $20 \mathrm{~min}$ at $2{ }^{\circ} \mathrm{C}$. The supernatant (cytosolic extract) and the pellet (lysosomal extract) were separated and the lysosomal fraction was resuspended in $3 \mathrm{~mL}$ of lysosome buffer $\left(20 \mathrm{mmol} \mathrm{L}^{-1}\right.$ sodium acetate, $\mathrm{pH}$ 5.0). Both fractions were aliquoted and stored at $-20^{\circ} \mathrm{C}$.

\section{Determination of activities of cathepsins $B, B+L$, $H$ and $D$}

The cysteine proteinases cathepsins $\mathrm{B}, \mathrm{B}+\mathrm{L}$ and $\mathrm{H}$ were assayed fluorimetrically (Cytofluor ${ }^{\mathrm{TM}}$ 2350, Millipore, Bedford, MA, USA) according to the method of Barret $^{22}$ with minor modifications. ${ }^{21}$ An excitation wavelength of $360 \mathrm{~nm}$ and an emission wavelength of $460 \mathrm{~nm}$ were used, with aminomethylcoumarin (Nmec) solutions as standards. Activities of subforms were measured on the basis of the following substrates: cathepsin B (EC 3.4.22.1), Z-Arg-Arg-Nmec; cathepsins B + L (EC 3.4.22.15), Z-Phe-Arg-Nmec (common substrate); cathepsin H (EC 3.4.22.16), Arg-NMec. Each unit of proteolytic activity of cathepsins $\mathrm{B}, \mathrm{B}+\mathrm{L}$ and $\mathrm{H}$ was defined as the amount of enzyme capable of releasing $1 \mu \mathrm{mol}$ of $\mathrm{Nmec}$ from the substrate per minute at $\mathrm{pH} 5.5$ and $37^{\circ} \mathrm{C}{ }^{21,22}$

The aspartate proteinase cathepsin D (EC 3.4.23.5) was assayed spectrophotometrically (Uvikon 930, 
Kontron Instruments, Milan, Italy) at $280 \mathrm{~nm}$ according to the procedure described by Takahashi and Tang, ${ }^{23}$ with minor modifications, ${ }^{21}$ using haemoglobin as substrate. A unit of proteolytic activity of cathepsin D was defined as that producing an increase of 0.01 absorbance units at $280 \mathrm{~nm}$ per minute at $\mathrm{pH} 3.3$ and $37^{\circ} \mathrm{C}$ measured as trichloroacetic acid (TCA)-soluble products from haemoglobin ( $1 \mathrm{~cm}$ light path). ${ }^{23}$

Protein concentrations were determined as described by Bradford ${ }^{24}$ and the results were expressed as enzyme milliunits $(\mathrm{mU}) \mathrm{mg}^{-1}$ protein for cathepsins $\mathrm{B}, \mathrm{B}+\mathrm{L}$ and $\mathrm{H}$ and as units $(\mathrm{U}) \mathrm{mg}^{-1}$ protein for cathepsin D.

All enzyme measurements were carried out in triplicate in both lysosomal and cytosolic extracts.

\section{Texture analysis}

LD samples (steaks) for texture analysis were thawed at $4{ }^{\circ} \mathrm{C}$ for $24 \mathrm{~h}$ in their vacuum-packed plastic bags, cooked at $75^{\circ} \mathrm{C}$ for $45 \mathrm{~min}$ by immersion in a water bath and then allowed to cool under tap water to $18^{\circ} \mathrm{C}$. Samples for the Warner-Bratzler (WB) shear test were obtained by cutting eight pieces, $1 \mathrm{~cm}^{2}$ in cross-section, parallel to the longitudinal orientation of the muscle fibres. These pieces were subjected to a WB shear blade until they split in an Instron 1011 machine (Instron Limited, High Wycombe, Bucks, UK). The maximum load (kg) required was recorded. Results are expressed as the mean WB maximum load value for each steak.

\section{Statistical analysis}

The effect of genotype on the enzyme activities and WB maximum load for each aging time was analysed by one-way analysis of variance (ANOVA). The effect of the aging period on each genotype and cathepsin activity was analysed by ANOVA with aging time and animal as fixed factors. When significant, differences between means were tested by the least significant difference (LSD) procedure. All statistical analyses were performed using the SPSS v11.5 program (SPSS, Inc, Chicago, Illinois, USA).

\section{RESULTS AND DISCUSSION}

Tables 1 and 2 show the enzyme activities of the cathepsins in the cytosolic and lysosomal extracts respectively throughout the meat aging period. Cytosolic and lysosomal cathepsin activities were considered separately so that we could describe the distributional changes produced in cathepsin activities during the course of meat aging in refrigerated conditions $\left(4^{\circ} \mathrm{C}\right)$.

We found that enzyme activity levels were generally higher in cytosolic extracts (Table 1) than in lysosomal extracts (Table 2), which could mean that leakage of enzymes from the lysosomes starts at an early stage. It is known that, in vivo, cathepsins are largely restricted to lysosomes. ${ }^{25}$ However, after slaughter, muscle $\mathrm{pH}$ decreases immediately and lysosomal membranes weaken and become leaky, ${ }^{26}$ such that lysosomal proteinases are gradually released and act on the myofibrils. In the present study this drop in $\mathrm{pH}$

Table 1. Effect of meat aging time $(3,7,14$ or 21 days) on activity of cathepsins $B, B+L, H$ and $D$ in cytosolic extracts. The activity of each cathepsin was compared separately for each genotype during the aging process

\begin{tabular}{|c|c|c|c|c|c|}
\hline \multirow[b]{2}{*}{ Cathepsin } & \multirow[b]{2}{*}{ Aging days } & \multicolumn{4}{|c|}{ Genotype } \\
\hline & & $m h / m h$ AV & $m h /+\mathrm{AV}$ & $+/+\mathrm{AV}$ & $+/+\mathrm{AM}$ \\
\hline $\mathrm{B}$ & 3 & $1.30 \mathrm{~b}$ & $1.10 \mathrm{ab}$ & 0.87 & $1.14 b$ \\
\hline \multirow[t]{4}{*}{$\left(\mathrm{mU} \mathrm{mg}^{-1}\right.$ protein) } & 7 & $1.34 b$ & $1.38 \mathrm{bc}$ & 0.68 & $0.78 a$ \\
\hline & 14 & $0.60 a$ & $1.64 \mathrm{c}$ & 0.84 & $1.14 b$ \\
\hline & 21 & & $0.85 a$ & 1.01 & $1.06 b$ \\
\hline & Significance & $* * *$ & $* * *$ & NS & $*$ \\
\hline$B+L$ & 3 & $1.13 a b$ & $1.23 a b$ & $0.97 a b$ & $0.88 a$ \\
\hline \multirow[t]{4}{*}{ (mU mg ${ }^{-1}$ protein) } & 7 & $1.49 \mathrm{~b}$ & $1.51 b$ & $0.75 a$ & $1.08 \mathrm{a}$ \\
\hline & 14 & $0.81 a$ & $2.07 c$ & $1.27 \mathrm{~b}$ & $1.88 b$ \\
\hline & 21 & & $0.95 a$ & $1.34 b$ & $1.26 a$ \\
\hline & Significance & $*$ & $* * *$ & $*$ & * \\
\hline $\mathrm{H}$ & 3 & $0.32 b$ & $0.48 b$ & $0.38 c$ & 0.40 \\
\hline \multirow{4}{*}{ (mU mg ${ }^{-1}$ protein) } & 7 & $0.51 c$ & $0.36 b$ & $0.25 b$ & 0.21 \\
\hline & 14 & $0.15 a$ & $0.32 \mathrm{ab}$ & $0.08 a$ & 0.12 \\
\hline & 21 & & $0.19 a$ & $0.37 c$ & 0.35 \\
\hline & Significance & $* * *$ & $*$ & $* * *$ & $* * *$ \\
\hline D & 3 & $24.74 b$ & $13.35 a$ & $16.78 a$ & $16.70 \mathrm{a}$ \\
\hline \multirow[t]{4}{*}{ (U mg ${ }^{-1}$ protein) } & 7 & $26.30 \mathrm{~b}$ & $21.85 b$ & $13.32 a$ & $14.63 a$ \\
\hline & 14 & $8.52 a$ & $24.91 \mathrm{c}$ & $17.61 a$ & $15.93 a$ \\
\hline & 21 & & $10.85 a$ & $30.11 b$ & $20.54 b$ \\
\hline & Significance & $* * *$ & $* * *$ & $* * *$ & * \\
\hline
\end{tabular}

For each cathepsin and genotype, means in columns followed by different letters differed significantly $(P<0.05)$, whereas the same letter indicates no significant differences. NS, no significant differences; * significant differences at $P<0.05$; ${ }^{* * *}$ significant differences at $P<0.001$. 
Table 2. Effect of meat aging time $(3,7,14$ or 21 days) on activity of cathepsins $B, B+L, H$ and $D$ in lysosomal extracts. The activity of each cathepsin was compared separately for each genotype during the aging process

\begin{tabular}{|c|c|c|c|c|c|}
\hline \multirow[b]{2}{*}{ Cathepsin } & \multirow[b]{2}{*}{ Aging days } & \multicolumn{4}{|c|}{ Genotype } \\
\hline & & $m h / m h$ AV & $m h /+\mathrm{AV}$ & $+/+\mathrm{AV}$ & $+/+\mathrm{AM}$ \\
\hline B & 3 & $0.83 b$ & $1.03 b$ & $0.92 \mathrm{c}$ & 0.94 \\
\hline \multirow{4}{*}{ (mU mg ${ }^{-1}$ protein) } & 7 & $0.88 \mathrm{~b}$ & $0.86 b$ & $0.88 \mathrm{bc}$ & 0.76 \\
\hline & 14 & $0.34 a$ & $0.85 b$ & $0.69 a$ & 0.88 \\
\hline & 21 & & $0.41 a$ & $0.72 a b$ & 0.74 \\
\hline & Significance & $* * *$ & $* * *$ & * & NS \\
\hline$B+L$ & 3 & $0.83 b$ & $0.75 b$ & 0.78 & 0.89 \\
\hline \multirow[t]{4}{*}{ (mU mg ${ }^{-1}$ protein) } & 7 & $1.21 \mathrm{c}$ & $1.14 \mathrm{C}$ & 0.75 & 1.05 \\
\hline & 14 & $0.40 a$ & $1.25 c$ & 0.91 & 1.26 \\
\hline & 21 & & $0.44 a$ & 1.01 & 0.66 \\
\hline & Significance & $* * *$ & $* * *$ & NS & NS \\
\hline $\mathrm{H}$ & 3 & $0.32 b$ & $0.35 b$ & 0.29 & $0.24 a$ \\
\hline \multirow[t]{4}{*}{ (mU mg ${ }^{-1}$ protein) } & 7 & $0.45 c$ & $0.38 \mathrm{~b}$ & 0.22 & $0.22 a$ \\
\hline & 14 & $0.14 a$ & $0.41 b$ & 0.34 & $0.38 b$ \\
\hline & 21 & & $0.16 a$ & 0.30 & $0.29 a b$ \\
\hline & Significance & $* * *$ & $* * *$ & NS & * \\
\hline $\mathrm{D}$ & 3 & 3.23 & $2.06 a$ & $2.10 a$ & $1.87 a$ \\
\hline \multirow[t]{4}{*}{ (U mg ${ }^{-1}$ protein) } & 7 & 4.65 & $3.24 b$ & $3.09 a$ & $3.53 b$ \\
\hline & 14 & 1.60 & $3.62 b$ & $5.22 b$ & $7.41 d$ \\
\hline & 21 & & $2.44 a$ & $2.89 a$ & $4.58 c$ \\
\hline & Significance & NS & ** & ** & $* * *$ \\
\hline
\end{tabular}

For each cathepsin and genotype, means in columns followed by different letters differed significantly $(P<0.05)$, whereas the same letter indicates no significant differences. NS, no significant differences; * significant differences at $P<0.05$; ** significant differences at $P<0.01$; ${ }^{* * *}$ significant differences at $P<0.001$.

differed significantly $(P<0.05)$ among genotypes, the final $\mathrm{pH}\left(\mathrm{pH}_{24}\right)$ being significantly lower in meat from AV yearling bulls with muscular hypertrophy, both in homozygosis $(m h / m h, 5.48)$ and heterozygosis $(m h /+$, 5.53), than in meat from normal $(+/+)$ AM animals (5.67), while meat from normal $(+/+)$ AV yearling bulls showed an intermediate $\mathrm{pH}$ value (5.58). This could be the result of a greater proportion of fasttwitch fibres and increased glycolytic metabolism in the LD muscle of double-muscled animals. ${ }^{16}$

Changes in the activity of cathepsins during meat aging showed a similar pattern in the lysosomes and cytosol, since two complementary processes are involved: the release of lysosomal proteases to the cytosol and a consistent breakdown of proteins by them, producing an increase in cleaning activity in the cell and enhancing endosomal vesicles, which interact with lysosomes, giving them new substrates to act on. ${ }^{27}$ Furthermore, our results indicated a similar activity pattern for all enzymes and genotypes, with increased activity early in the meat aging process and decreased activity in later periods. However, a more in-depth analysis of data revealed a significant effect of genotype on this process. Thus the activity of cathepsins in the LD muscle of double-muscled $\mathrm{mh} / \mathrm{mh}$ animals decreased at 14 days, while this drop in activity for heterozygous $m h /+$ bulls was observed at 21 days. Normal $+/+$ animals of both breeds did not show this reduction or the decrease was smaller than for the other genotypes. All cathepsins in both types of extract followed this pattern of activity (e.g. cytosolic cathepsin D showed $32.40 \%$ of its maximal activity in meat of the $m h / m h$ genotype at 14 days $v s$ $43.56 \%$ in $m h /+$ bulls at 21 days; cytosolic cathepsin B activity was $44.78 \%$ in $\mathrm{mh} / \mathrm{mh}$ meat at 14 days $v s$ $51.83 \%$ in $\mathrm{mh} /+$ meat at 21 days). This higher activity of acidic enzymes at short aging times in meat from bulls with muscular hypertrophy $(m h / m h$ and $m h /+)$ than in meat from normal bulls $(+/+)$ may be related to the differences found among genotypes in muscle $\mathrm{pH}$ recorded at $24 \mathrm{~h}$ post mortem.

Furthermore, the faster post mortem acidification of the LD muscle in animals with muscular hypertrophy $(m h / m h$ or $m h /+)$ and its positive influence on cathepsin activities in both lysosomal and cytosolic extracts affected the tenderisation rate, as shown in Fig. 1. Meat from AV bulls homozygous $m h / m h$ or heterozygous $m h /+$ for muscular hypertrophy showed a faster tenderisation rate than meat from normal $+/+\mathrm{AV}$ or AM animals. This produced significant differences among genotypes in WB shear force values after long storage times (14 and 21 days; Fig. 1), indicating that meat from AM bulls was tougher than meat from AV animals.

These results confirm the importance of cathepsins as the main proteolytic system in long-term meat aging under refrigerated conditions. Our data highlight the significant effect of muscle $\mathrm{pH}$ in later stages of the storage process on the rate of release of cathepsins from the lysosomes to the cytosol, conditioning meat toughness. These data are also consistent with previous data reported by Campo et al. ${ }^{12}$ and Oliván et al. ${ }^{19}$ indicating that meat tenderisation was faster in doublemuscled bulls than in other genotypes. 


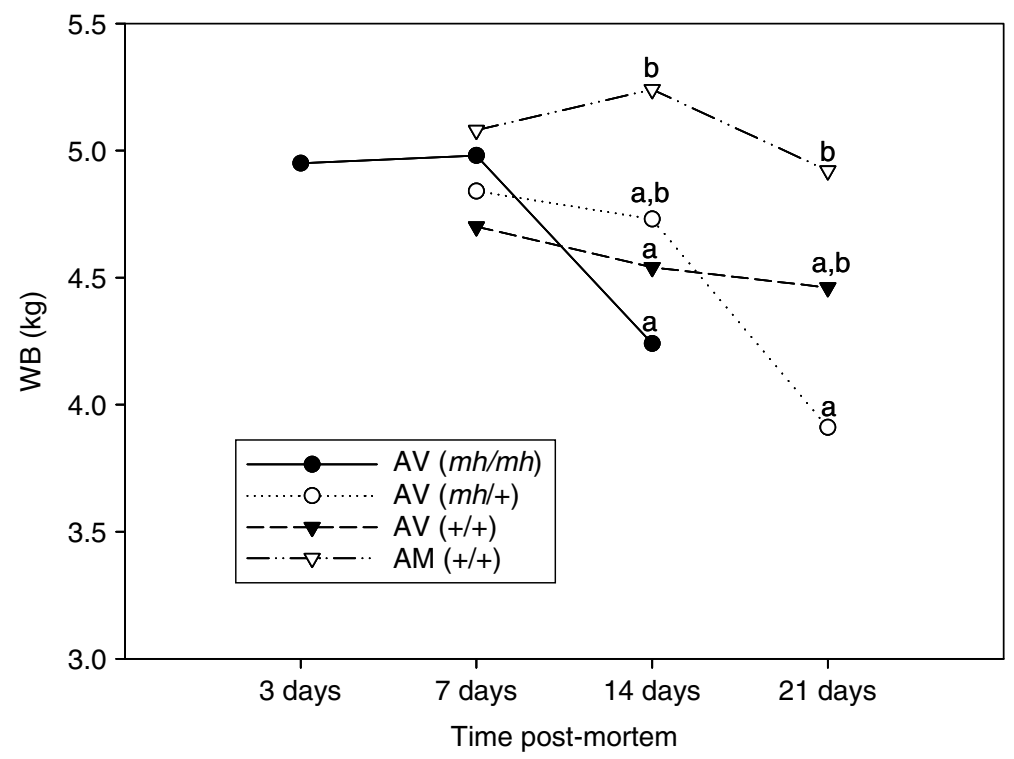

Figure 1. Warner-Bratzler (WB) shear force recorded in meat samples from four genotypes $(\bullet,(m h / m h) A V ; O,(m h /+) A V ; \nabla,(+/+) A V ; \nabla,(+/+)$ AM) during post mortem aging period. Means of WB shear force were compared between genotypes for each time point. Means with different letters were significantly different at the $P<0.05$ level, whereas the same letter indicates no significant differences.

Several studies have shown the importance of cathepsin activities during late post mortem when the muscle approaches its final $\mathrm{pH} .{ }^{26}$ Increased activity of cathepsins $\mathrm{B}+\mathrm{L}$ in the soluble fraction of muscle homogenates has been observed after 8 days of storage of pork longissimus muscle ${ }^{28}$ and up to 14 days in the pectoralis profundus of cattle ${ }^{29}$ Moreover immunolabelling of cathepsin $\mathrm{D}$ has revealed that this enzyme is present outside the lysosomes after 14 days post mortem storage of beef. ${ }^{29}$ This is also consistent with studies performed on ostrich ${ }^{30}$ and lamb ${ }^{31}$ demonstrating that cathepsin activity is related to meat tenderness from day 1 post mortem until the end of the characteristic aging period for each type of meat.

With regard to the relative importance of each cathepsin in the proteolytic process, levels of enzyme activity were different for the different cathepsins examined. Thus cathepsin D showed the highest activity in both extracts and cathepsin $\mathrm{H}$ the lowest, while cathepsins B and B $+\mathrm{L}$ showed relatively low levels of activity. There are several works indicating that cathepsins $\mathrm{B}, \mathrm{L}$ or $\mathrm{B}+\mathrm{L}$ contribute most to post mortem proteolysis, ${ }^{9,26}$ but in most of those studies the activity of cathepsin D was not assayed. Our results support the findings of Rico et al. ${ }^{32}$ in that cathepsin D was considered to be the most important proteolytic enzyme in the post mortem proteolysis of porcine muscle, with a crucial role in changes in meat texture. Indeed, the role of cathepsin D as a regulator of cysteine proteases has been suggested. ${ }^{33}$ The low activity of cystatins as endogenous inhibitors of cathepsins $\mathrm{B}, \mathrm{L}$ and $\mathrm{H}$ detected in the LD muscle ${ }^{9}$ seems to support the role of cathepsin $\mathrm{D}$ as the main controller of cysteine protease activity in this muscle. Hence cathepsin D could be responsible for the low activity of cathepsins $\mathrm{B}, \mathrm{L}$ and $\mathrm{H}$ observed here.
We observed an increase over time in detectable cathepsin D activity in cytosolic extracts of normal genotypes $(+/+)$ of both cattle breeds $\left(16.8-30.1 \mathrm{U} \mathrm{mg}^{-1}\right.$ protein for AV and $16.7-20.5 \mathrm{U}$ $\mathrm{mg}^{-1}$ protein for AM; Table 1). This rise was not produced at the expense of a comparable loss of lysosomal activity, which was already too low after 14 days (Table 2). Jung et al. ${ }^{34}$ also observed increased cathepsin $\mathrm{D}$ activity during beef aging even when high hydrostatic pressure was applied during the maturation process.

Procathepsin $\mathrm{D}$, as a cathepsin $\mathrm{D}$ precursor, requires specific excision by lysosomal cysteine proteases ${ }^{35}$ to be active. In addition, some authors ${ }^{9,26}$ have found that cathepsins B and B $+\mathrm{L}$ exhibit highest activity post mortem in early maturation periods. Collectively, these data seem to indicate that cathepsins B and B + $\mathrm{L}$ could work early during the tenderisation process, not only on specific protein substrates but also in cathepsin D activation. It is known that cathepsins can attack contractile proteins at differents strategic points. ${ }^{36}$ Thus the specific activation mechanism of cathepsin D and increased amounts of its substrate produced by the earlier activity of cathepsins $B$ and $\mathrm{B}+\mathrm{L}$ could explain the high activity of cathepsin D observed here in later maturation periods.

The differences observed in cathepsin D activity between extracts highlight the particular role of this enzyme in proteolysis during meat storage. Our findings suggest some remaining integrity of a lysosome subpopulation, which may continue to be partly functional. Previous studies ${ }^{37}$ demonstrated that the breakdown of lysosomes is almost complete at 14 days of storage. However, in the present study we found that even at 21 days post mortem there are entire lysosomes where cathepsins still seem to function. This would indicate that some peptide fragments formed as 

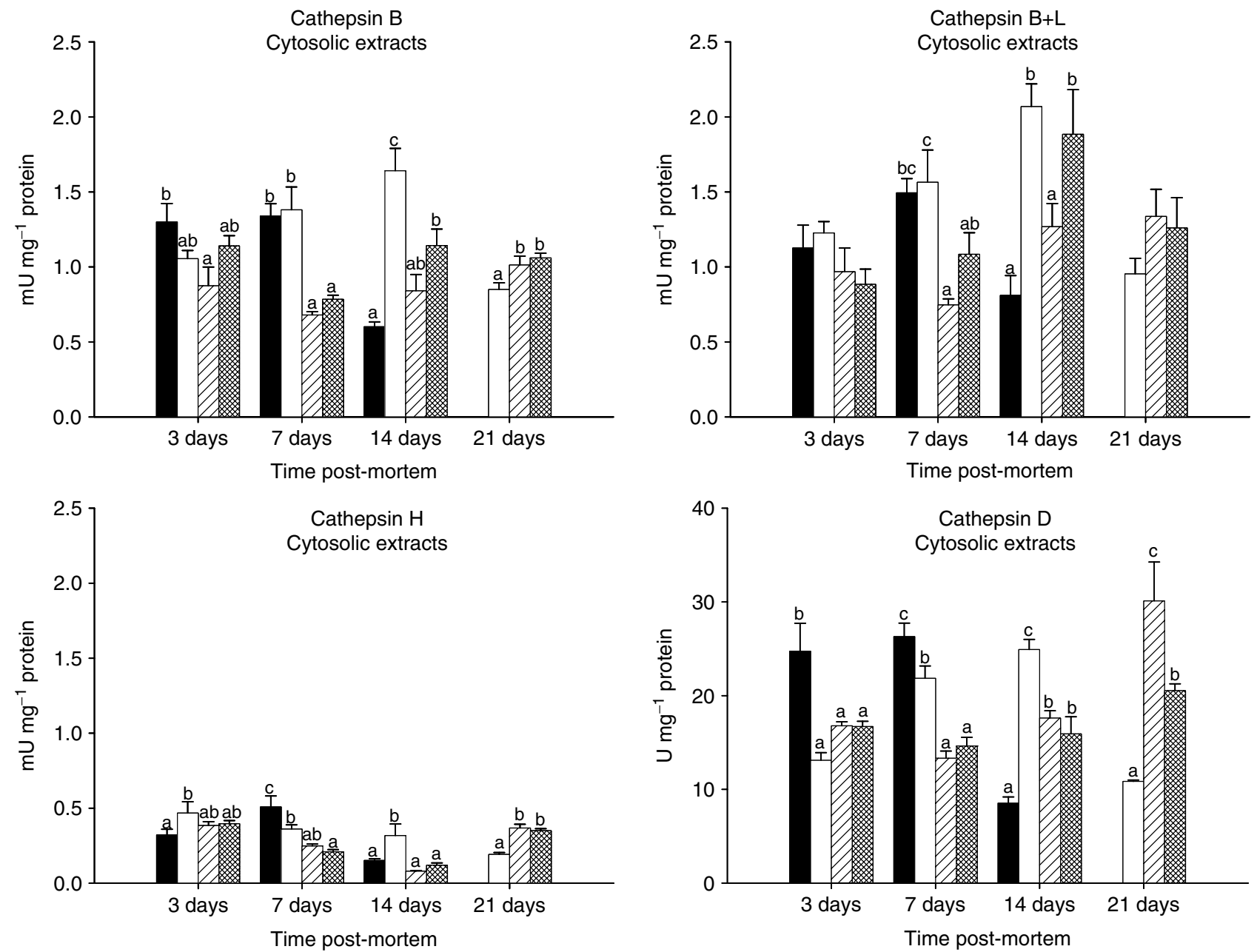

Figure 2. Changes in cathepsin $B, B+L, H$ and $D$ activities in cytosolic extracts of meat from four genotypes $(\mathbf{\square},(m h / m h) A V ; \square,(m h /+) A V$; 囚, (+/+) AV; 圆, (+/+) AM) during post mortem aging period. Values are shown as mean \pm standard error of mean $(n=5)$. Cathepsin activity means were compared between genotypes for each time point. Means with different letters were significantly different at the $P<0.05$ level, whereas the same letter indicates no significant differences.

a consequence of post mortem proteolysis will not be available as substrates for free cytosolic cathepsins.

The activity of cathepsin D in the cytosol showed different patterns in double-muscled $(\mathrm{mh} / \mathrm{mh}$ and $m h /+)$ and normal $+/+$ animals of both breeds (Fig. 2). In animals with muscular hypertrophy the activity of cathepsin D was high at early and medium storage times (3-7 and 7-14 days in $\mathrm{mh} / \mathrm{mh}$ and $\mathrm{mh} /+$ animals respectively) and showed a large decrease after long-term storage (14 and 21 days respectively). However, in meat from $+/+\mathrm{AV}$ and $+/+\mathrm{AM}$ yearling bulls, which showed a lower tenderisation rate than double-muscled animals, as indicated in Fig. 1, there was a continuous increase in cathepsin D activity in the cytosol during the aging period. This could indicate an important role for cathepsin $\mathrm{D}$ at the end of the tenderisation process, which seems to be prolonged in these genotypes. Moreover, before post mortem proteolytic activity drops, a continued tenderisation process in this group of animals will mean that a longer maturation period will be required to reach the same level of tenderness as meat from doubled-muscled animals. Similarly, the trend shown by cathepsin D in cytosol extracts (Fig. 2) of meat from heterozygous animals $m h /+$ to significantly rise $(P<0.05)$ at 7 and 14 days post mortem and then drop $(P<0.05)$ at 21 days could explain why the meat of $m h /+$ animals showed an intermediate tenderisation rate between those of doubled-muscled and normal animals.

The activity of cathepsins $\mathrm{B}, \mathrm{B}+\mathrm{L}, \mathrm{D}$ and $\mathrm{H}$ at early stages of the aging process ( 3 and 7 days) was higher in meat from AV yearling bulls with muscular hypertrophy $(m h / m h$ and $m h /+)$ than in meat from normal $+/+\mathrm{AV}$ and AM animals in both extracts (e.g. cytosolic cathepsin B activity was $1.34 \mathrm{mU} \mathrm{mg}^{-1}$ protein for $m h / m h \mathrm{AV}$ at 7 days vs 0.68 and $0.78 \mathrm{mU} \mathrm{mg}^{-1}$ protein for $+/+\mathrm{AV}$ and $+/+\mathrm{AM}$ respectively), but significant differences were only attained in the cytosolic compartment (in both compartments for cathepsin $\mathrm{H})$. This could be related to the lower $\mathrm{pH}$ detected in the LD from these animals at early post mortem stages, which activates cell membrane breakdown processes and enhances the release of lysosomal proteases to the cytosol, as proposed by Berge et al. ${ }^{29}$ The same tendency was observed for cathepsins $\mathrm{D}$ and $\mathrm{H}$ (e.g. cytosolic cathepsin D activity was $26.30 \mathrm{U} \mathrm{mg}^{-1}$ protein for $m h / m h \mathrm{AV}$ at 7 days vs 13.32 and $14.63 \mathrm{U} \mathrm{mg}^{-1}$ protein for $+/+\mathrm{AV}$ and $+/+\mathrm{AM}$ respectively; Fig. 2), 

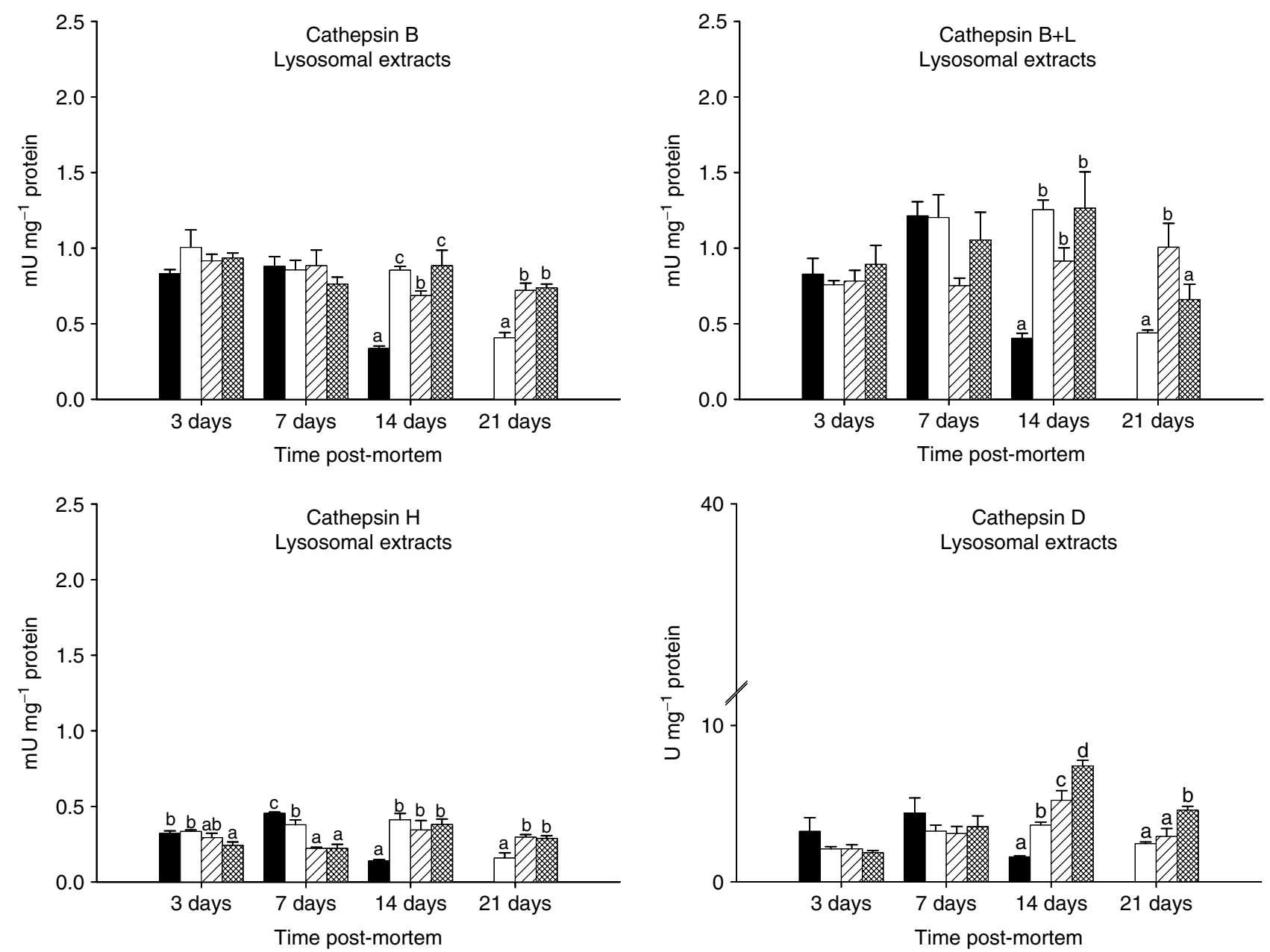

Figure 3. Changes in cathepsin B, B $+\mathrm{L}, \mathrm{H}$ and $\mathrm{D}$ activities in lysosomal extracts of meat from four genotypes $(\mathbf{\square},(\mathrm{mh} / \mathrm{mh}) \mathrm{AV} ; \square,(\mathrm{mh} /+) \mathrm{AV}$; $\square,(+/+) \mathrm{AV} ;$ 圆, (+/+) AM) during post mortem aging period. Values are shown as mean \pm standard error of mean $(n=5)$. Cathepsin activity means were compared between genotypes for each time point. Means with different letters were significantly different at the $P<0.05$ level, whereas the same letter indicates no significant differences.

so it seems that the proteolytic process was faster in the double-muscled animals, producing meat that was more tender earlier on than meat from the other genotypes.

Late in the aging process the activity of most cathepsins $(\mathrm{B}, \mathrm{B}+\mathrm{L}$ and $\mathrm{H})$ decreased in both the lysosomal and cytosolic compartments (Fig. 2 and Fig. 3), probably owing to increased protein damage during the post mortem course, which could affect enzyme efficiency. This decrease was more pronounced in the double-muscled animals than in the other genotypes, with the former showing an activity drop of $\sim 60 \%$ compared with $<30 \%$ for the latter. Heterozygous $m h /+\mathrm{AV}$ animals underwent an intermediate decrease.

In conclusion, our findings suggest that the activity of cathepsins during the course of long-term meat aging (3-21 days) parallels the meat tenderisation process, revealing an essential role for cathepsins as proteolytic enzymes in long-term meat maturation. Furthermore, clear differences were detected in the action patterns of the different cathepsins throughout the maturation period. Cathepsins $\mathrm{B}$ and $\mathrm{B}+\mathrm{L}$ act before cathepsin $\mathrm{D}$, which becomes more important in the later stages of aging (14-21 days). In contrast, it seems that cathepsin $\mathrm{H}$ does not contribute significantly to the tenderisation process.

The present findings also provide further support for a link between the tenderisation rate and mutations in the myostatin gene that lead to muscular hypertrophy. Faster cathepsin activity was observed in meat from the $\mathrm{LD}$ of homozygous $\mathrm{mh} / \mathrm{mh}$ double-muscled yearling bulls than in meat from heterozygous $m h /+$ animals, which was in turn faster than the activities recorded in beef from normal $+/+\mathrm{AV}$ and $\mathrm{AM}$ bulls. However, more work is required to establish the role of cathepsins in the tenderisation process of meat from different muscles and from animals subjected to different production systems. This type of study will provide further information on the metabolic effects produced on this endogenous proteolytic system.

\section{ACKNOWLEDGEMENTS}

We thank the staff of Livestock Production Systems of SERIDA for their skilled management of animals and carcasses, Luis Guerrero (IRTA) for advice on the statistical analyses, and Dr Koldo Osoro (SERIDA) 
for useful suggestions concerning the experimental design and comments on the manuscript. This study was supported by INIA (Instituto Nacional de Investigación y Tecnología Agraria y Alimentaria) under projects SC00-14 and CAL03-074-C2 and FEDER funds. B Caballero is recipient of a fellowship from FICYT, Spain, V Sierra of a predoctoral fellowship from INIA, Spain. I Vega-Naredo is recipient of a FPU fellowship from the Ministerio de Educación y Ciencia, Spain. A Coto-Montes is a researcher from the Ramón y Cajal Program (Ministerio Educación y Ciencia), Spain.

\section{REFERENCES}

1 Jiang ST, Contribution of muscle proteinases to meat tenderization. Proc Natl Sci Council B 22:97-107 (1998).

2 Hattori A and Takahashi K, Studies on the post-mortem fragmentation of myofibrils. Biochem f 85:47-56 (1979).

3 Gann GL and Merkel RA, Ultrastructural changes in bovine Longissimus dorsi muscle during post-mortem aging. Meat $\mathrm{Sci}$ 2:129-144 (1978).

4 Koohmaraie M, Muscle proteinases and meat aging. Meat Sci 36:93-98 (1994).

5 Geesink GH and Koohmaraie M, Technical note: a rapid method for quantification of calpain and calpastatin activities in muscle. F Anim Sci 77:3225-3229 (1999).

6 Christensen M, Larsen LM, Ertbjerg P and Purslow PP, Effect of proteolytic enzyme activity and heating on the mechanical properties of bovine single muscle fibres. Meat Sci 66:361-369 (2004).

7 Sentandreu MA, Coulis G and Ouali A, Role of muscle endopeptidases and their inhibitors in meat tenderness. Trends Food Sci Technol 13:400-421 (2002).

8 Thompson BC, Dobbie PM, Cox NR and Simmons NJ, Differences in the post-mortem kinetics of the calpain system in meat from bulls and steers. NZ $\mathcal{f}$ Agric Res 42:47-54 (1999).

9 Koohmaraie M, Seideman SC, Schollmeyer JE, Dutson TR and Babiker AR, Factors associated with the tenderness of three bovine muscles. F Food Sci 53:407-410 (1988).

10 Whipple G and Koohmaraie M, Effects of animal age, muscle type and 24-hour activity of endogenous proteinases on postmortem proteolysis. F Anim Sci 70:798-804 (1992).

11 Koohmaraie $M$, Biochemical factors regulating toughening and tenderization processes of meat. Meat Sci 43:193-201 (1996).

12 Campo MM, Santolaria P, Sañudo C, Lepetit J, Olleta JL, Panea B, et al, Assessment of breed type and ageing time effects on beef meat quality using two different texture devices. Meat Sci 55:371-378 (2000).

13 Monsón F, Sañudo C and Sierra I, Influence of cattle breed and ageing time on textural meat quality. Meat Sci 68:595-602 (2004).

14 Arthur PF, Double muscling in cattle: a review. Aust F Agric Res 46:1493-1515 (1995).

15 Bouton PE, Harris PV and Shorthose WR, Comparison of some properties of beef from animals homozygous or heterozygous for muscular hypertrophy. Meat Sci 6:309-318 (1982).

16 Oliván M, Martínez A, Osoro K, Sañudo C, Panea B, Olleta JL, et al, Effect of muscular hypertrophy on physico-chemical, biochemical and texture traits of meat from yearling bulls. Meat Sci 68:567-575 (2004).

17 Grobet L, Royo Martin LJ, Poncelet D, Pirottin D, Brouwers B, Riquet J, et al, A deletion in the bovine myostatin gene causes the double-muscled phenotype in cattle. Nat Genet 17:71-74 (1997).

18 Thomas M, Langley B, Berry C, Sharma M, Kirk S, Bass J, et al, Myostatin, a negative regulator of muscle growth, functions by inhibiting myoblast proliferation. 7 Biol Chem 275:40235-40243 (2000).

19 Oliván M, Mocha M, Martínez A, Castro P and Osoro K, Evolución post-mortem de la dureza instrumental de la carne de distintos genotipos de las razas bovinas asturianas. ITEA 24:43-45 (2003).

20 Béchet D, Obled A and Deval C, Species variations amongst proteinases in liver lysosomes. Biosci Rep 6:991-997 (1986).

21 Schreurs FJG, Van Der Heide D, Leenstra FR and De Wit W, Endogenous proteolytic enzymes in chicken muscles. Differences among strains with different growth rates and protein efficiencies. Poultry Sci 74:523-537 (1995).

22 Barret AJ, Fluorimetric assays for cathepsin B and cathep$\sin \mathrm{H}$ with methylcoumarylamide substrates. Biochem $\mathcal{f}$ 187:909-912 (1980).

23 Takahashi $\mathrm{T}$ and Tang J, Cathepsin $\mathrm{D}$ from porcine and bovine spleen. Meth Enzymol C 80:565-581 (1981).

24 Bradford MM, A rapid and sensitive method for the quantitation of microgram quantities of protein utilizing the principle of protein-dye binding. Anal Biochem 72:248-254 (1976).

25 Roncales P, Geesink GH, Van Laack RL, Jaime I, Beltrán JA, Barnier VH, et al, Meat tenderization: enzymatic mechanisms, in Expression of Tissue Proteinases and Regulation of Protein Degradation as Related to Meat Quality, ed. by Ouali A, Demeyer DI and Smulders FJ. ECCEAMST, Utrecht, pp. 311-332 (1995).

26 Etherington DJ, The contribution of proteolytic enzymes to post-mortem changes in muscle. F Anim Sci 59:1644-1650 (1984).

27 Alberts B, Johnson A, Lewis J, Raff M, Roberts K and Walter P, et al, Internal organization of the cell, in Molecular Biology of the Cell (4th edn), ed. by. Alberts B, Johnson A, Lewis J, Raff M, Roberts K, Walter P. Garland Science, New York, 583-1062 (2002).

28 Ertbjerg P, Henckel P, Karlsson A, Larsen LM and Moller AJ, Combined effect of epinephrine and exercise on calpain/calpastatin and cathepsin B and 1 activity in porcine longissimus muscle. f Anim Sci 77:2428-2436 (1999).

29 Berge P, Ertbjerg P, Larsen LM, Astruc T, Vignon X and Moller AJ, Tenderization of beef by lactic acid injected at different times post mortem. Meat Sci 57:347-357 (2001).

30 Thomas AR, Gondoza H, Hoffman 1C, Oosthuizen V and Naudé RJ, The roles of the proteasome and cathepsins B, L, $\mathrm{H}$ and $\mathrm{D}$ in ostrich meat tenderisation. Meat Sci 67:113-120 (2004).

31 Nagaraj NS, Anilakumar KR and Santhanam K, Changes in the calpain-calpastatin and cathepsin (B, B + L, H and D) during post-mortem storage of goat muscles. F Food Biochem 26:75-89 (2002).

32 Rico E, Toldra F and Flores J, Assay of cathepsin D activity in fresh pork muscle and dry-cured ham. Meat Sci 28:331-348 (1991).

33 Lenarci B, Krasovec M, Ritonja A, Olafsson I and Turk V, Inactivation of human cystatin $\mathrm{C}$ and kininogen by human cathepsin D. FEBS Lett 280:211-215 (1991).

34 Jung $S$, Ghoul $M$ and de Lamballerie-Anton $M$, Changes in lysosomal enzyme activities and shear values of high pressure treated meat during ageing. Meat Sci 56:239-246 (2000).

35 Samarel AM, Ferguson AG, Decker RS and Lesch M, Effects of cysteine protease inhibitors on rabbit cathepsin D maturation. Am f Physiol 257:C1069-C1079 (1989).

36 Lawrie RA, Conversion of muscle into meat: biochemistry, in The Chemistry of Muscle-based Food, ed. by Johnston DE, Knight MK and Ledward DA. Royal Society of Chemistry, Cambridge, pp. 43-55 (1992).

37 Zeece MG, Woods TL, Keen MA and Reville WJ, Role of proteinases and inhibitors in postmortem muscle protein degradation. Proc 45th Annu Recip Meat Conf, Fort Collins, CO, pp. 51-61 (1992). 